\title{
Recent Migration Studies in Turkey
}

\section{Ayşem Biriz Karaçay}

\section{(2) OpenEdition}

\section{Journals}

Electronic version

URL: https://journals.openedition.org/remi/3401

DOI: $10.4000 /$ remi.3401

ISSN: $1777-5418$

\section{Publisher}

Université de Poitiers

\section{Printed version}

Date of publication: 31 December 2006

Number of pages: 225-228

ISBN: 978-2-911627-43-9

ISSN: 0765-0752

\section{Electronic reference}

Ayşem Biriz Karaçay, "Recent Migration Studies in Turkey", Revue européenne des migrations internationales [Online], vol. 22 - n³ | 2006, Online since 31 December 2009, connection on 16 April 2022. URL: http://journals.openedition.org/remi/3401 ; DOI: https://doi.org/10.4000/remi.3401

This text was automatically generated on 16 April 2022

(c) Université de Poitiers 


\title{
Recent Migration Studies in Turkey
}

\author{
Ayşem Biriz Karaçay
}

\section{EDITOR'S NOTE}

Nous proposerons une seconde revue sur la production turque récente dans un numéro ultérieur de la REMI, sur la base des travaux d'autres centres de recherche et d'autres éditeurs.

1 This book review presents a collection of five books from the Migration Series of Istanbul Bilgi University Publishing, all of which are reflecting different level of analysis within the framework of different theoretical backgrounds on recent migration studies. Of course, these books are also illustrating the current research trends and methodologies used and applied in the recent Turkish migration studies. Migration Studies Series are one of the prominent categories of the Istanbul Bilgi University Publishing. They offer new perspectives, emerging formulations and a variety of historical and analytical approaches to the ongoing debates in the field of migration.

\section{Abadan-Unat Nermin (2002) Bitmeyen Göç: Konuk Işçilikten Ulus-ötesi Yurttaşlığa (Unending Migration: from Guest-worker to Transnational Citizen), İstanbul Bilgi University Press Series on Migration Studies.}

2 To begin with the work of Nermin Abadan-Unat, a prominent and well-known scholar in this field, Bitmeyen Göç: Konuk İsçilikten Ulus-ötesi Yurttaşlı̆̆a (Unending Migration: from Guest-worker to Transnational citizen) delineates on the external migration from Turkey, the demographic movements and its impacts on Turkish society within the context of a strong theoretical background and an extensive literature review. This book, through the findings of the field researches carried out in the Western Germany and Holland, 
examines the transformation of the Turkish migrants who went as provisional "guestworker" to go West Germany in the 1960's and then to other European countries on the basis of bilateral agreements. Elaborating the increasing level of Turkish migrants' remittances in the early 1980's and its impact on the social, demographic and cultural structure of Turkish society, the author also evaluates the transition in the settlement of migrants into an ideological, ethnic and general characteristics of the Turkish migrant women. In her last two chapters, the author assesses the impact of globalization by putting emphasize on the transnational communities and the dilemnas emerged from the formulations / implementations of the international migration policies.

\section{Toksöz Gülay (2006) Uluslararası Emek Göçü (International Labour Migration) Istanbul Bilgi University Press, Migration Studies Series, Istanbul.}

3 Gülay Toksöz, examines how migration is closely tied to the movements of goods and capital. Toksöz provides the role of different structural dynamics in the international labour migration and put special emphasize on the stratification in the labour market and demographic changes in the European society. While analyzing the impact of the globalization on the labour migration flows, she also looks at the main characteristics of the Turkish labour and the migration potential from Turkey to Europe both of which are among the highly debated topics in the EU-TR membership agenda. On her concluding remarks, she proposes timely policy recommendations with the new formulations/suggestions on the population decrease and the labour need in Europe in the coming years. Apart from these two books which are mainly focused on the different dynamics of the Turkish labour migration, there are other books published by Istanbul Bilgi University which concentrate on the migrants, their integration problems and their social environment.

\section{Richter Michael (2005) Geldiler ve Kaldılar... Almanya Türkleri'nin Yaşam Öyküleri (They Came and Stayed... Life Stories of Turks in Germany) translated by Mutlu Çomak Özbatır, Istanbul Bilgi University Press, Migration Studies Series, Istanbul.}

Michael Richter's book "Geldiler ve Kaldılar... Almanya Türkleri'nin Yaşam Öyküleri” (They Came and Stayed... Life Stories of Turks in Germany) -composed of the life stories of the first generation of Turkish workers- make an exposition on how, dramatically, the first generation of Turkish workers in Germany adapted to German Society and how they deal with the problems in the process of constructing their life in a completely different society. Workers, students, merchants and craftsmen remember their roots and traditions in their country of origin, the years of hardships in a foreign country, their process of adaptation to a new society, their materialized and non-materialized dreams and their new lives reconstructed through their changing destiny. This book is an illuminating book, since it is one of the main sources for understanding the 
migrants and their real feelings which sometimes blurred and ignored in the current security and globalization focused-discussions on international migration. Interestingly, the life stories of these first generation migrants from different social, cultural and economic backgrounds make the readers to clearly understand the baggage of the migrants they brought to the receiving country and sometimes dramatic transitions in their lives and perceptions as time goes by.

These life stories prove that the first generation of Turkish migrants in Germany do not come from a rural background, on the contrary they manifest that some part of those people had previously lived abroad, some of them had lived in towns and cities in Turkey and a section of them had previously migrated to Turkey from the European territory which had been under the Ottoman rule once upon time.

\section{Vassaf Gündüz (2004) Daha Sesimizi Duyuramadık (We also have something to say: Children of Turkish workers in Germany) İstanbul Bilgi University Press, Series on Migration Studies, Istanbul.}

6 Nermin Özdil, whose fotograph is seen on the cover, is one of those people... Why did Özdil leave Turkey in 1973 while she was a young woman? Why did she stay in Germany? For Nermin Özdil, who has been living in Germany for fourty years, Hamburg is the home where she lives and Turkey is a country of holidays and memories. Isn't Turkey now the country of holidays and memories for much of the Turks living in German-Gündüz Vassaf, in this book, focused on the second generation and examines the cultural changes-that the children of Turkish workers have created-within those children's life world. While suggesting that cultural identities take form in all the spaces and dimensions of a given society, in all the mundane spheres of life such as the school and the street etc., he also points out that religion and ethnicity are the prominent determinants of identity in a mutual interaction.

\section{Erder Sema (2006) Refah Toplumunda “Getto" ve Turkler (Ghetto and Turks in the Welfare Society) İstanbul Bilgi University Press Series on Sociology, Istanbul.}

7 Sema Erder's book "Refah Toplumunda 'Getto' ve Türkler" (Ghetto and Turks in the Welfare Society), with the field study conducted in Rinkeby, a small town near to Stockholm, clearly defines the discouraging role of the "getto" life on the integration of the Turkish migrants, its various impacts on their social status, interactions and family relations. While doing this, she analyzes what "getto" theoretically means considering urbanization and segregation in Stockholm. This book is a reedition of the study written and publied in the 1980's by the Author (Sema Köksal at this time) with the aid of UNESCO founds. A part of the book defined the somewhat difficult traductions from Western languages and notions to Turkish language. 


\section{Kaya Ayhan and Kentel, Ferhat (2005) Euro-Türkler Türkiye Ille Avrupa Birliği Arasında Köprü mü Engel mi? (Euro-Turks: A Bridge or A Breach Between Turkey and the European Union), İstanbul Bilgi University Press Series on Migration Studies, Istanbul.}

and an impediment to Turkey's EU membership. Thus, the research has aimed at investigating whether Euro-Turks living in Germany and France could become a driving force or in their words as a bridge for Turkey in the process of integration into the European Union. It also seeks to determine whether these communities could provide new opportunities and prospects for the formation of a more open and a more democratic society in Turkey. At this stage, Kaya and Kentel's research reveals that there are three major groups of Euro-Turks emerging in the migratory process: bridging groups (who are affiliated with both the homeland and 'host-land') breaching groups (who still have a strong orientation to the homeland) and assimilated groups. Based on a survey of the literature and structured interviews, this report reveals how Euro-Turks demonstrate the fact that Europeanness is not a prescribed identity, but an ongoing process of being and becoming. This categorization is an important entry point for understanding and analyzing the "Europeaness". Thus, Euro-Turks contribute to the redefinition of the EU and being European with their own social, political, cultural and economic identities.

11 All these books are available at:

- Istanbul Bilgi Üniversitesi, Göç Çalışmaları Uygulama ve Araştırma Merkezi İnönü Caddesi n 28, Kuştepe, 34387 şişli - ISTANBUL, Türkiye / Turkey / Turquie

- Neşe ERD İLEK, İdarî Direktör / Adminsistrative Manager, Tel: (+ 90 212) 3116546 Fax: (+ 90_212) 21684 36http://goc.bilgi.edu.tr, e-mail: nerdilek@bilgi.edu.tr; migcenter@cmr.bilgi.edu.tr 


\section{AUTHOR}

\section{AYŞEM BIRIZ KARAÇAY}

Centre de Recherche sur les Migrations de l'Université Koç, Istanbul. 